\title{
Pemisahan Ion Tembaga Pada Limbah Pengolahan Emas Tradisonal Menggunakan Asam Lemak Hidroksamat Dari Minyak Kelapa
}

\author{
Muhsinun \\ Program Studi Pendidikan Ilmu Pengetahuan Alam, Institut Pendidikan Nusantara Global, Praya - \\ NTB \\ Corresponding Author: cinun.chemist@gmail.com
}

\begin{abstract}
Abstrak: Dalam limbah pengolahan emas tradisional memungkinkan terdapatnya penumpukan logam-logam khususnya logam $\mathrm{Cu}$, sehingga diperlukan suatu metode pemisahan dan perolehan kembali pada kondisi lingkungan tersebut guna mengurangi bahaya yang disebabkan oleh salah satu logam berat ini. Telah dilakukan penelitian tentang pemisahan ion logam tembaga dari logam lainnya dengan metode ekstraksi padat-cair menggunakan kromatografi kolom. Kolom ini mengandung asam lemak hidroksamat (FHA) yang di sintesis dari minyak kelapa dan telah diimmobilisasi ke dalam resin Amberlite XAD-4. Adapun beberapa parameter yang diteliti, yaitu pengaruh konsentrasi FHA, massa resin Amberlite XAD-4 dan pH larutan sampel. Dari penelitian ini diperoleh perbandingan kondisi optimum untuk pemisahan logam $\mathrm{Cu}$ adalah sebagai berikut: konsentrasi FHA 50 ppm; 0,5 gram resin Amberlite XAD-4; larutan ion logam $\mathrm{Cu}$ pada pH 5. Untuk pemisahan logam $\mathrm{Cu}$ (II) dari beberapa logam lainnya seperti $\mathrm{Zn}$ (II), $\mathrm{Pb}$ (II) dan $\mathrm{Cd}$ (II) telah berhasil dilakukan pada $\mathrm{pH} 5$ dan diperoleh besarnya serapan logam $\mathrm{Cu}$ (II) dalam resin sebesar $6,26 \mathrm{mg} / \mathrm{g}$.
\end{abstract}

Kata kunci: Pemisahan, ion Cu (II), Asam Lemak Hidroksamat, FHA, Minyak Kelapa

Abstract: In traditional gold waste processing it is possible to have a cumulation of metals, especially $\mathrm{Cu}$, in that so it is needed a separation method and recovery for these environmental condition in order to reduce the risk caused by one of these heavy metals. A research has been conducted on the separation of copper metal ions from other metals by solid-liquid extraction method using column chromatography. This column contains fatty hydroxamic acids (FHA) which synthesized from coconut oil and has been immobilized onto Amberlite XAD-4 resin. As for several parameters investigated, those are namely, the effect of FHA concentration, mass of Amberlite $X A D-4$ resin and the $p H$ of the sample solution. The result of this research is obtained that the comparison of optimum conditions for $\mathrm{Cu}$ metal separation is as follows: 50 ppm FHA concentration; 0.5 gram of Amberlite XAD-4 resin; $C u$ metal ion solution at $5 \mathrm{pH}$. The separation of $\mathrm{Cu}$ (II) metal from several other metals such as $\mathrm{Zn}$ (II), Pb (II) and Cd (II) have been successfully carried out at $5 \mathrm{pH}$ and the amount of adsorption of $\mathrm{Cu}(\mathrm{II})$ obtained by resin was $6.26 \mathrm{mg} / \mathrm{g}$.

Keywords: separation, $\mathrm{Cu}$ (II) ions, fatty hydroxamic acid, FHA, coconut oil

\section{PENDAHULUAN}

Kandungan logam dalam limbah tambang tradisional biasanya hanya terbuang sia-sia dan menjadi bahan pencemar lingkungan. Jadi, pengolahan terhadap limbah logam yang terbuang tersebut sangat perlu dilakukan daripada harus membuangnya secara sia-sia sehingga pada akhirnya tidak menimbulkan pencemaran lingkungan yang lebih parah. Untuk memperoleh kembali logam-logam tersebut dalam penanggulangannya terhadap pencemaran lingkungan itu dapat digunakan beberapa metode, seperti ekstraksi pelarut atau metode immobilisasi chelating agent dalam resin untuk memisahkan logam-logam dari air limbah. Namun perolehan kembali logamlogam dengan menggunakan metode ekstraksi pelarut memunculkan permasalahan baru, yaitu sebagian besar pelarut organik yang digunakan untuk mengekstraksi logam tersebut masih bersifat toksik (racun) jika 
dibuang langsung ke lingkungan, sehingga dalam penelitian ini digunakanlah metode immobilisasi chelating agent dalam resin. Metode immobilisasi ini memudahkan pemisahan dan perolehan kembali logamlogam dari limbahnya dikarenakan chelating agent yang terikat pada fase padat resin akan mengikat logam-logam yang terkandung dalam air limbah. Metode ini disebut juga dengan ekstraksi padat-cair, dengan resin yang mengikat chelating agent sebagai fase padat dan air limbah sebagai fase cairnya. Melalui metode ini diharapkan dapat memisahkan dan memperoleh kembali logamlogam dalam limbah, khususnya logam $\mathrm{Cu}$ tanpa menimbulkan permasalahan baru terhadap lingkungan.

Beberapa penelitian terdahulu menggunakan chelating agent dengan reagen tertentu untuk mengekstraksi logam berat dari limbah ini dan penggunaannya pun mengalami perkembangan dari tahun ke tahun, seperti 8alkarylsulphonamidoquinoline LIX 34 yang digunakan Dukov et al., (1982) kemudian tahun 1984, Inoue et al., menggunakan anti-2hydroxy-5-nonylacetophenoneoxime SME 529, sedangkan oleh Yoshizuka et al., tahun 1990 menggunakan 5-dodecylsalicylaldoxime LIX 860. Dan pada tahun 1997, Sandhibiguaha et al., menggunakan reagen dasar ketoxime-LIX 87QN. Namun reagenreagen ini masih merupakan reagen komersial yang mahal dan sulit diperoleh. Untuk itu diperlukan suatu reagen yang murah dan mudah diperoleh dalam penanggulangannya terhadap pencemaran lingkungan, sehingga dalam penelitian ini digunakan reagen yang mempunyai gugus asam hidroksamat dengan bahan dasar asam lemak. Reagen dengan gugus asam hidroksamat merupakan reagen yang mempunyai sifat pengkhelat logam yang tinggi dan superior untuk ekstraksi dan pemisahan spektrometer dari ion logam (Agrawal et al., 1980). Penelitian Zaki (2001) tentang pembuatan poli (asam lemak hidroksamat) dengan bahan dasar pati sagu ternyata dapat digunakan untuk mengekstraksi logam golongan unsur Lantanida baik dari lingkungan maupun dari sumber lainnya, sehingga dapat disimpulkan bahwa reagen asam lemak hidroksamat ini mempunyai kemampuan tinggi dalam mengekstraksi logam.

Menurut Suhendra (2005), asam lemak hidroksamat (FHA) mempunyai sifat chelating agent yang sangat baik dan dapat digunakan untuk mengekstraksi ion $\mathrm{Cu}$ (II) dari fase airnya. Namun reagen yang digunakan pada penelitian ini terbuat dari minyak kelapa sawit yang memang cukup sulit diperoleh di daerah NTB, khususnya Lombok Tengah, sehingga reagen ini akan dibuat dari minyak kelapa yang juga mengandung asam lemak, baik itu berupa rantai sedang maupun panjang. Minyak kelapa mengandung lebih dari $95 \%$ trigliserida (trigliserol) serta beberapa jenis asam lemak jenuh dan tidak jenuh (Vossen, 2001). Dengan mengubah trigliserida menjadi ester maka diharapkan asam lemak hidroksamat dapat disintesis dari minyak kelapa dan dapat digunakan pada pemisahan dan perolehan kembali logam-logam dalam limbah tambang emas tradisional.

\section{METODOLOGI PENELITIAN}

\section{Alat dan Bahan}

Adapun peralatan yang digunakan dalam penelitian, yaitu semua peralatan dasar dari gelas di laboratorium kimia, magnetic stirrer-pemanas, magnetic bar, shaker, pompa vakum, timbangan digital, statif-klem, $\mathrm{pH}$ meter digital, kromatografi kolom, UV-Vis, AAS. Adapun bahan yang digunakan berderajat P.A (Pro Analyze) kecuali yang disebut khusus. Bahan tersebut adalah sebagai berikut: resin Amberlite XAD-4, methanol, nheksana, minyak kelapa, hidroksilamin hidroklorida, enzim Lipase, buffer asetat, $\mathrm{NaOH}, \mathrm{HCl}$, Vanadium, logam nitrat $(\mathrm{Cu}, \mathrm{Zn}$, $\mathrm{Pb}, \mathrm{Cd}), \mathrm{HNO}_{3}$, Aquades, $\mathrm{pH}$ universal Merck dan kertas saring Whatman.

\section{Immobilisasi FHA pada Amberlite XAD-4}

Resin Amberlite XAD-4 direndam dengan methanol selama 24 jam, kemudian dicuci dengan $\mathrm{HCl} 6 \mathrm{M}$, aquades, $\mathrm{NaOH} 2 \mathrm{M}$, dan aquades. Setelah penyaringan, resin dicampurkan dengan 2000 ppm larutan FHA dalam methanol dan dikocok pada $35 \mathrm{rpm}$ selama 24 jam.

Pengaruh konsentrasi FHA terhadap daya serapan Amberlite XAD-4 
Sebanyak 0,5 $\mathrm{g}$ bagian dari resin Amberlite XAD-4 dikocok dengan $20 \mathrm{~mL}$ FHA dalam methanol pada $35 \mathrm{rpm}$ selama 12 jam (konsentrasi FHA berada dalam kisaran 50-250 ppm). Serapan FHA dalam Amberlite XAD-4 diukur secara spektrofotometri. Satu mL FHA, sebelum dan setelah dikocok dengan Amberlite XAD-4, ditambahkan dengan $10 \mathrm{~mL}$ methanol dan $0,1 \mathrm{~mL}$ larutan Besi $0,1 \mathrm{M}$ dalam $\mathrm{HCl}$ 0,01M. Kemudian, absorbansi diukur menggunakan spektrofotometer UV-Vis pada panjang gelombang maksimumnya untuk kalkulasi besarnya kapasitas serapan resin.

Pengaruh pH terhadap serapan ion logam oleh FHA-Amberlite XAD-4

Pengaruh $\mathrm{pH}$ ini ditentukan oleh teknik kesetimbangan kontinu. Sebanyak $20 \mathrm{~mL}$ ion logam standar $\mathrm{Cu}^{2+} 0,001 \mathrm{M}$ dikocok dengan $100 \mathrm{mg}$ FHA-Amb selama 12 jam untuk memastikan kesetimbangan tercapai pada semua kondisi. Untuk $\mathrm{pH}$ dari larutan ion logam diatur antara $\mathrm{pH}$ 1-6 dengan 0,01M larutan buffer asetat sebelum dikocok. Setelah setimbang, konsentrasi ion dalam larutan ditentukan menggunakan AAS untuk kalkulasi besarnya kapasitas serapan.

Ekstraksi padat-cair pada ion logam dengan menggunakan Resin Amberlite XAD-4

Sejumlah 4 g FHA-Amb dimasukkan kedalam sebuah kolom dengan diameter dalam $1 \mathrm{~cm}$ dan tinggi $10 \mathrm{~cm}$. Kemudian sebanyak $100 \mathrm{~mL}$ larutan campuran yang mengandung ion logam $\mathrm{Cu}, \mathrm{Zn}, \mathrm{Pb}, \mathrm{Cd}$ dengan konsentrasi masing-masing 100 ppm, dikondisikan pada $\mathrm{pH}$ maksimum (berdasarkan prosedur diatas dan ditentukan dengan $0,01 \mathrm{M}$ buffer asetat), kemudian dilewatkan melewati kolom dengan kecepatan alir 0,3-0,4 mL/menit. Konsentrasi ion $\mathrm{Cu}$ (II) sebelum dan setelah melewati kolom ditentukan menggunakan AAS untuk kalkulasi persentase serapan ion logam $\mathrm{Cu}$ (II).

HASIL DAN PEMBAHASAN

Immobilisasi FHA dalam Resin Amberlite XAD-4

Pengaruh konsentrasi FHA terhadap daya serapan Amberlite XAD-4
FHA mudah larut pada pelarut polar, sehingga dilakukan persiapan larutan induk FHA 2000 ppm dalam metanol. Dari penelitian terdahulu menyebutkan bahwa alkohol merupakan pelarut yang bagus untuk FHA (Suhendra, 2005). Perlakuan yang sama juga dilakukan pada resin Amberlite XAD-4, yaitu direndam dengan methanol selama 24 jam, kemudian dicuci dengan $\mathrm{HCl} 6 \mathrm{M}$, aquades, $\mathrm{NaOH} 2 \mathrm{M}$, dan aquades hingga netral. Perendaman ini dimaksudkan untuk mengaktivasi sisi aktif dari resin sehingga dapat memudahkan immobilisasi dari asam lemak hidroksamat dalam resin Amberlite XAD-4.

Tahap awal dilakukan pencarian panjang gelombang maksimum pada larutan metanolik dari FHA setelah ditambahkan ion $\mathrm{Fe}^{3+} 0,1 \mathrm{M}$ dalam $\mathrm{HCl}$ 0,01M. Penentuan panjang gelombang maksimum ini dibutuhkan untuk mendapatkan kepekaan analisis yang maksimum sehingga sangat menentukan berhasil atau tidaknya penelitian ini. Berdasarkan Gambar 4. setelah dilakukan analisis UV-Vis diperoleh bahwa senyawa kompleks Fe-FHA terbentuk optimum pada panjang gelombang $484 \mathrm{~nm}$. Hal ini dikarenakan warna komplementer yang dihasilkan oleh senyawa kompleks ini berwarna merah dan menyerap sinar pada daerah tampak (visibel). Hasil pengukuran tersebut juga sesuai dengan penelitian yang dilakukan oleh Demirhan (2003), yang menyatakan bahwa warna merah kompleks Fe dengan beberapa ligan berkisar antara 470$520 \mathrm{~nm}$.

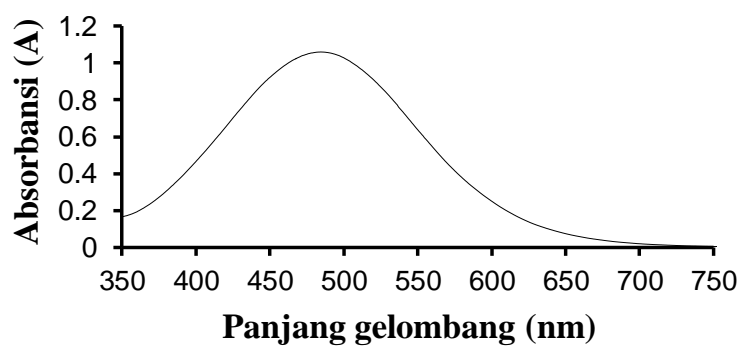

Gambar 4. Spektrum UV-Vis pada FHAmetanol-Fe ${ }^{3+}$

Jumlah FHA yang terimmobilisasi kedalam Amberlite XAD-4 sebagai fungsi dari konsentrasi FHA ditunjukkan pada Gambar 5. Pada gambar grafik tersebut terdapat pengaruh konsentrasi FHA terhadap 
persen jerapannya dalam resin, terlihat bahwa persen serapan FHA oleh adsorben menurun dengan meningkatnya konsentrasi awal FHA, kemudian konstan setelah tercapai kesetimbangan. Hal ini terjadi karena meningkatnya konsentrasi awal FHA akan memberikan daya dorong yang lebih besar. Hasilnya, kandungan FHA akan berpindah (migrasi) dari permukaan luar ke dalam poripori resin Amberlite yang berukuran mikro. Dengan meningkatnya konsentrasi awal dari FHA, efisiensi penghilangan menurun sehingga semakin tinggi konsentrasi larutan FHA maka lebih banyak FHA yang terserap. Namun jika dikonversi dalam bentuk persen diperoleh persen serapan yang semakin kecil seiring dengan bertambahnya konsentrasi FHA.

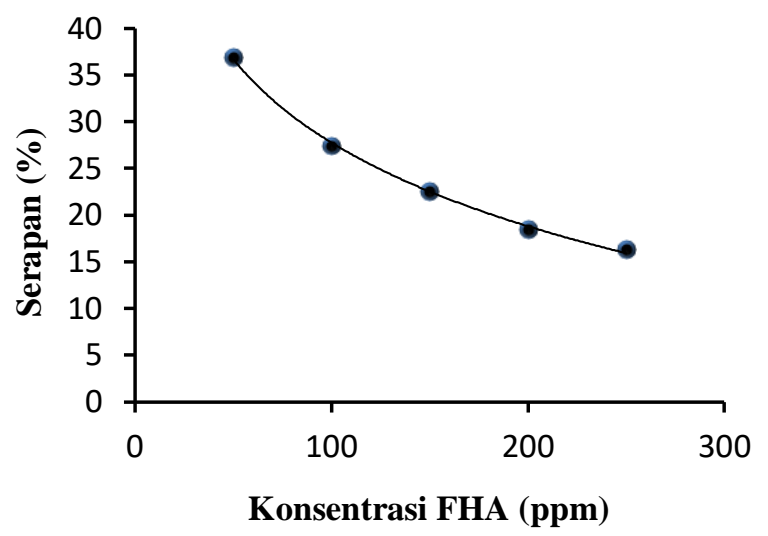

Gambar 5. Pengaruh konsentrasi FHA terhadap persen jerapannya dalam resin

Dari Gambar 5, juga diketahui bahwa pada konsentrasi $50 \mathrm{ppm}$ dari FHA, resin mencapai serapan maksimum, yaitu sebesar $36,94 \%$ atau sekitar $18,47 \mathrm{mg} /$ gram resin. Tingkat efisiensi penggunaan bahan juga perlu dipikirkan, semakin kecil bahan yang digunakan dan menghasilkan persen jerapan yang besar maka akan sangat efisien digunakan sebagai bahan baku pengkhelat logam sehingga hanya pada konsentrasi 50 ppm yang dapat digunakan untuk keperluan optimasi selanjutnya.

Hasil optimasi lanjutan tentang pengaruh massa resin terhadap persen jerapan FHA ditunjukkan pada Gambar 6, yang dikondisikan pada variasi massa resin dengan konsentrasi FHA yang tetap yaitu $50 \mathrm{ppm}$. Pada grafik itu menunjukkan bahwa seiring dengan bertambahnya massa resin dihasilkan persen serapan yang semakin kecil.. Jika dilihat dari besarnya serapan FHA pada variasi massa resin, memang terjadi kenaikan dari setiap variasi itu namun tidak sebanding dengan kenaikan massa resin. Hal ini disebabkan besarnya konsentrasi FHA yang dapat terjerap dalam resin dipengaruhi oleh jumlah mol maksimum gugus asam hidroksamat yang terkandung dalam FHA 50 ppm tersebut. Data sintesis menunjukkan besarnya konsentrasi FHA yang mempunyai gugus asam hidroksamat adalah setara dengan $2,99 \mathrm{mmol} / \mathrm{gram}$ atau sebesar $41,9 \mathrm{mg} / \mathrm{gram}$ FHA. Setelah dilakukan analisis, diperoleh kapasitas maksimum dari immobilisasi FHA dalam resin Amberlite XAD-4 terdapat pada massa resin 0,5 gram yaitu sebesar $36,68 \%$ atau $18,34 \mathrm{mg} / \mathrm{g}$ resin.

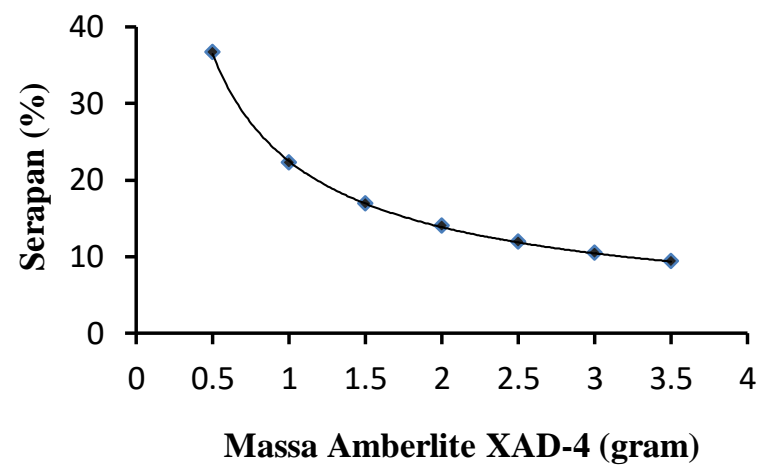

Gambar 6. Pengaruh massa Amberlite XAD4 terhadap persen jerapan FHA

Pengaruh pH terhadap serapan ion logam oleh FHA-Amberlite

Menurut Khopkar (1990), menyatakan bahwa perubahan $\mathrm{pH}$ akan mempengaruhi stabilitas warna kompleks. Oleh karena itu diperlukan penentuan $\mathrm{pH}$ optimum. Derajat keasaman $(\mathrm{pH})$ optimum untuk ekstraksi ditunjukkan dengan besarnya serapan ion logam oleh FHA-Amberlite. Terlihat pada Gambar 7, bahwa persentase ekstraksi dari ion logam $\mathrm{Cu} 2+$ meningkat seiring meningkatnya $\mathrm{pH}$ dan kembali menurun setelah $\mathrm{pH}$ optimumnya ( $\mathrm{pH}$ 5). 


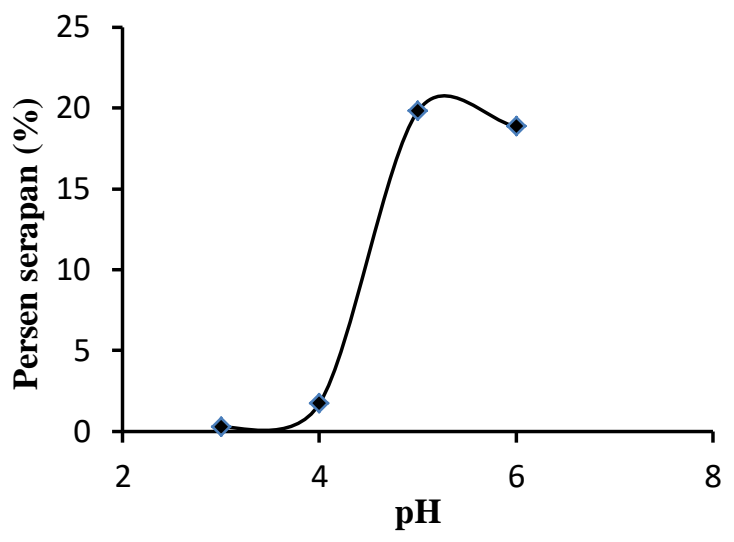

Gambar 7. Pengaruh $\mathrm{pH}$ terhadap persen jerapan oleh FHA-Amberlite

Umumnya untuk mengetahui serapan dari logam Tembaga (II) dalam FHAAmberlite dapat diujikan pada nilai $\mathrm{pH}$ berbeda dengan menggunakan metode kontinu dan hasilnya ditunjukkan pada grafik diatas. Hasil itu mengindikasikan bahwa ion logam $\mathrm{Cu}^{2+}$ menunjukkan kapasitas serapan maksimumnya pada pH 5. Dan ini disebabkan adanya kestabilan kompleks dari $\mathrm{Cu}-\mathrm{FHA}$ yang terbentuk pada proses ekstraksi. Kapasitas resin juga adalah salah satu faktor penting dalam menentukan jumlah resin yang diperlukan untuk memindahkan secara kuantitatif sebuah spesifik ion logam dari suatu larutan.

Ekstraksi padat-cair pada ion logam $\mathrm{Cu}^{2+}$ dengan menggunakan Resin Amberlite XAD-4

Pada tahap ekstraksi padat-cair ini digunakan metode kromatografi kolom, yang dalam hal ini menggunakan buret dengan diameter dalam $1 \mathrm{~cm}$ sebagai kolomnya. Besarnya pH optimum pada Gambar 7 . digunakan sebagai kondisi awal dari sampel yang diukur serapannya dalam resin. Hal ini bertujuan untuk mengetahui tingkat kestabilan kompleks yang dihasilkan dari logam-logam sampel. Preparasi awal dilakukan dengan memasukkan sebanyak 4 gram FHAAmberlite yang telah disiapkan pada proses ekstraksi sebelumnya. FHA yang terimmobilisasi dalam resin haruslah masih dalam keadaan basah oleh larutan metanolik FHA, dimaksudkan agar sisi aktif dari khelatnya dapat berfungsi dengan baik.
Sejumlah $100 \mathrm{~mL}$ larutan campuran yg terdiri dari $\mathrm{Cu}, \mathrm{Zn}, \mathrm{Pb}$ dan $\mathrm{Cd}$ dengan konsentrasi masing-masing 100 ppm dikondisikan pada $\mathrm{pH}$ optimum $(\mathrm{pH} 5)$, dan dilewatkan melalui kolom tersebut. Penelitian Suhendra (2005) menyatakan bahwa kecepatan alir antara $0,3-0,4 \mathrm{~mL} / \mathrm{menit}$ sangat baik digunakan untuk menentukan besarnya serapan ion logam $\mathrm{Cu}^{2+}$ pada resin Amberlite.

Tabel 2. Serapan ion logam dalam kolom FHA-Amberlite

\begin{tabular}{ccc}
\hline Ion logam & $\begin{array}{c}\text { Konsentrasi } \\
(\mathrm{ppm})\end{array}$ & Serapan (\%) \\
\hline $\mathrm{Cu}$ & 100 & 25,04 \\
$\mathrm{Zn}$ & 100 & 0,74 \\
$\mathrm{Cd}$ & 100 & 1,53 \\
$\mathrm{~Pb}$ & 100 & 6,76 \\
\hline
\end{tabular}

Dengan metode AAS diperoleh besarnya pengukuran serapan ion logam dalam resin Amberlite seperti terlihat pada Tabel 2. Data diatas menunjukkan bahwa ion logam $\mathrm{Cu}$ terjerap paling besar dalam resin dibandingkan dengan logam yang lainnya. $\mathrm{Hal}$ ini disebabkan karena logam $\mathrm{Cu}$ mempunyai kestabilan kompleks yang tinggi, yaitu pada $\mathrm{pH}$ optimum tersebut $(\mathrm{pH} 5)$, sedangkan logam lainnya kurang stabil sehingga hanya bisa terjerap sedikit saja. Jika dianalisa secara keseluruhan, besarnya serapan logam $\mathrm{Cu}$ dalam resin mencapai $25,04 \%$ atau sebesar 25,04 ppm. Nilai ini menunjukkan bahwa dalam setiap 1 gram FHA-Amberlite terdapat $6,26 \mathrm{ppm}$ ion logam $\mathrm{Cu}^{2+}$ yang terjerap.

\section{KESIMPULAN}

Berdasarkan hasil penelitian dan kajian pustaka yang telah dilakukan, maka dapat disimpulkan bahwa FHA yang disintesis dari minyak kelapa dapat digunakan sebagai pengkhelat logam pada proses pemisahan dan perolehan kembali logam $\mathrm{Cu}$ (II), dengan kondisi optimum FHA 50 ppm; 0,5 gram Amberlite XAD-4; larutan ion logam $\mathrm{Cu}$ (II) pada $\mathrm{pH}$ 5. Untuk pemisahan logam $\mathrm{Cu}$ (II) dari beberapa logam lainnya seperti Zn (II), $\mathrm{Pb}$ (II) dan $\mathrm{Cd}$ (II) telah berhasil dilakukan pada $\mathrm{pH} 5$ dan diperoleh besarnya serapan logam $\mathrm{Cu}$ (II) dalam resin sebesar 6,26 mg/g. 


\section{DAFTAR PUSTAKA}

Agrawal, Y.K.; Patel, S.A. 1980. Hydroxamic acid; Reagents for the solvent extraction and spectrophotometric determination of metals. Rev. Anal. Chem. 4:237-276.

Arsiwan, R. 2010 Sintesis Asam Lemak Hidroksamik Dari Minyak Kelapa Secara Enzimatis. Universitas Mataram, Mataram.

Creswell, C.J., Runquist, O.A., M.M. Campbell. 1982. Analisis Spektrum Senyawa Organik. ITB, Bandung.

Demirhan, N., Tuncel, E. F. 2003. Spectrophotometric Determination of Iron(II) with 5-Nitro-6-amino-1,10phenanthroline. Turkey J. Chem. Vol. 27, 315 - 321

Dukov, I.L., Guy, S. 1982. Solvent extraction of zinc(II) and copper(II) with mixtures of LIX 34 and versatic 911 in kerosene. Hydrometallurgy. 8:77-82.

Inoue, K., Tsunomachi, H. 1984. Solvent Extraction Equilibria of Copper and Nickel with SME 529. Hydrometallurgy. 13:73-87.

Khopkar, S.M. 1990. Konsep Dasar Kimia Analitik. Universitas Indonesia, Jakarta.

Sandhibiguaha, A., Sarma, P.V.R.B. 1997. Co-extraction and selective stripping of copper and nickel using LIX87QN. Hydrometallurgy. 45:211-219.

Suhendra, D., Wan Yunus, W.M.Z., Haron, M.J., Basri M., Silong, S. 2005. Enzymatic synthesis of fatty hydroxamic acid from palm oil. Journal Oleo Science. 54 (1): 33-38.

Suhendra, D. 2005. Copper Ion Extraction by a Mixture of fatty Hidroxamic Acids Synthesized from Commercial Palm Oil. Solvent Extraction and Ion Exchange. 23: 713-723.

Vogel. 1990. Analisis Kualitatif Makro dan Semimikro. Terjemahan Kalman Media Pustaka, Jakarta.

Vossen, H.A.M.V.D., B.E. Umail (eds.). 2001. Plant Resources of South East Asia No. 14 Vegetable Oil and Fats. Backhuys. Leiden.
Yoshizuka, K., Arita, H., Baba, Y., Inoue, K. 1990. Equilibria of Solvent Extraction of Copper(II) with 5dodecylsalicylaldoxime. Hydrometallurgy. 23: 247-261.

Zaki, M.A.R., Rahman M.L., Haron M.J., Silong S., Wan Yunus, W.M.Z., Ahmad, M.B. 2001. Preliminary Study on Application of Sago Starch Based Poly(HydroxamicAcid) Resin for Extraction of Lanthanide Group Elements from Aqueous Media. Malaysian Journal of Analytical Sciences. 7 (2): 453-456. 